\title{
ACTIVITY OF ENZYMES OF TYROSINE METABOLISM IN THE RAT LIVER UNDER THE CONDITIONS OF ACETAMINOPHEN-INDUCED HEPATITIS ON THE BACKGROUND OF PROTEIN DEFICIENCY
}

\author{
O. M. VOLOSHCHUK, H. P. KOPYLCHUK \\ Department of Biochemistry and Biotechnology \\ Institute of Biology, Chemistry and Bioresources \\ Yuriy Fed'kovych Chernivtsi National University, \\ Kotsyubinskogo str., 2, Chernivtsi, 58012, Ukraine, \\ e-mail:o.voloschuk@chnu.edu.ua
}

\begin{abstract}
The contribution of the mis-metabolism of individual amino acids to the development of drug-induced damage to liver cells remains unexplored. The aim of the present study was to investigate the changes in liver tyrosine level and activity of the enzymes of its metabolism: tyrosine aminotransferase, 4-hydroxyphenylpyruvate dioxygenase, aldehyde dehydrogenase ALDH3A1 under the conditions of acetaminophen-induced hepatitis on the background of protein deficiency. Determination of tyrosine in deproteinized with $6 \%$ sulfosalicylic acid extracts of the liver tissue was performed using the automatic analyzer of amino acids T-339 ("Microtechnology", Czech Republic). The enzyme activity was determined by spectrophotometric method - tyrosine aminotransferase by the amount of 4hydroxybenzaldehyde, which has a maximum absorption at $330 \mathrm{~nm}$, 4-hydroxyphenylpyruvate dioxygenase - by the colored product intensity at $\lambda 336 \mathrm{~nm}$, aldehyde dehydrogenase ALDH3A1 activity was measured at $340 \mathrm{~nm}$ wavelength. Results have shown that in animals with toxic liver injury which were maintained in conditions of alimentary protein deficiency, a 5-fold decrease in tyrosine level in the liver was observed. At the same time in animals of this group there was a decrease in TAT activity by 1.6 times, a 4-fold decrease in activity of aldehyde dehydrogenase ALDH3A1 and increase in the activity of 4-hydroxyphenylpyruvate dioxygenase by 2.5 time comparing to control parameters. Conclusion was made, that alimentary protein deficiency is a factor leading to an intensification of tyrosine metabolism disturbances in animals with toxic liver injury. The pronounced exhaustion of the tyrosine pool is accompanied by the activation of the homogentisate pathway of its metabolism, as evidenced by the increase in the activity of 4-hydroxyphenylpyruvate dioxygenase and simultaneous reduction in the aldehyde dehydrogenase ALDH3Alactivity. The established changes open prospects to study the possible targets for the exogenous correction of metabolic disorders under the conditions of intoxication with acetaminophen, especially in people with protein deficiency.
\end{abstract}

Keywords: animal model, protein deficiency, liver, paracetamol, tyrosine

Introduction. To date, an issue of finding the molecular targets for the correction of metabolic processes in conditions of toxic liver injury remains open. Mechanisms of the metabolic disorders formation in conditions of the toxic influence of a number of drugs, including acetaminophen (APAP), are known today (Ramachandran and Jaeschk, 2017; Yoon et al., 2016; Lee, 2017). However, the contribution of the mis-metabolism of individual amino acids to the development of drug-induced damage to liver cells remains unexplored. There are only some literature data about the specificities of the amino acids metabolism, in particular aromatic, under the conditions of liver disease of different etiology (Mukherjee et al., 2010; Jin et al., 2016).

APAP-induced acute toxicity has become an essential model for studying drug-induced liver injury. In the liver, APAP overdose produces a centrilobular hepatic necrosis that can be fatal and is increasingly recognized as a significant public health problem. Moreover, APAP overdose is also the second leading cause of liver transplantation, which accounts for considerable levels of morbidity and mortality (Mobasher and Valverde, 2014).

The liver is known to play a central role in amino acid metabolism (Dejong et al., 2007), so liver damage, including as a result of exposure to toxic doses of drugs, leads to multiple metabolic abnormalities. However, despite significant progress in our understanding of APAP-induced hepatotoxicity, additional mechanisms responsible for the cellular damage induced by this drug, especially in conditions of essential nutrients deficiencies, still remain unknown. Particularly interesting is the study of the peculiarities of tyrosine metabolism in the liver under the conditions of its toxic injury in animals with varying supply of dietary protein.

It is known that dietary protein is the main source of tyrosine for animals, while tyrosine can also be synthesized from the essential amino acid phenylalanine. About $30 \%$ of tyrosine is used to synthesize catecholamines, melanin and thyroid hormones, and part of it - to build tissue proteins. More than $60 \%$ of tyrosine enters the liver where it is 
oxidized in transamination reaction with the participation of a pyridoxal-dependent enzyme tyrosine aminotransferase to form 4hydroxyphenylpyruvate, which can be further metabolized in two ways: homogentisate pathway, with the formation of fumarate and acetoacetate, which are used as substrates in energy metabolism reactions; or be converted to 4-hydroxybenzoate - a precursor of the benzoyl ring of the ubiquinone molecule, the component of the respiratory chain of mitochondria (Rass, 2010; Pahari et al., 2016; Antonenko et al., 2015; Chernykh, 2013).

Since the direction of tyrosine metabolism under the conditions of toxic acetaminophen-induced injury in protein-deficient animals remains unexplored, the aim of this research was to determine the tyrosine content and activity of tyrosine aminotransferase (EC 2.6.1.5), 4-hydroxyphenylpyruvate dioxygenase (EC 1.13.11.27), aldehyde dehydrogenase ALDH3A1 (EC 1.2.1.3) in liver and cortisol blood serum level of rats.

Materials and methods. Animal ethics. The experiments were performed on white rats with a body weight of 100-150 $\mathrm{g}$ and 2.5-3 months of age. Animal maintenance and manipulations were conducted in accordance with the article 26 of the Law of Ukraine № 3447-IV 21.02.2006 "On the protection of animals from cruelty", "The European Convention for the Protection of Vertebrate Animals used for Experimental and Other Scientific Purposes" (Strasbourg, 1986), "General Ethical Considerations for Animal Experimentation" established by First Ukrainian Congress on Bioethics (Kyiv, 2001).

Experimental design. The animals were placed into plastic cages with sand bedding and ad libitum access to water. The daily rations were regulated according to principles of pair feeding.

The animals were divided into the experimental groups: I - animals receiving a standard semisynthetic ration for 28 days (C); II - animals with acetaminophen-induced hepatitis receiving a full ration $(\mathrm{H})$; III - animals subjected to acetaminopheninduced liver injury and previously maintained on a low-protein semi-synthetic ration $(\mathrm{LPR}+\mathrm{H})$.

The animals of the group I were fed with a standard fodder containing 14\% protein (casein), 10\% fat, and $76 \%$ carbohydrates, balanced by all the essential nutrients. The animals of the group II received an isoenergetic fodder containing 4.7\% protein, $10 \%$ fat, and $85.3 \%$ carbohydrates, calculated according to the recommendations of the American Institute of Nutrition (Reeves et al., 1993). The animals were fed the corresponding diet for four weeks. Afterwards, the acetaminophen-induced liver injury was modeled by per os administration of $2 \%$ starch suspension of acetaminophen at a dose of 1 $\mathrm{g} / \mathrm{kg}$ body weight for 2 days. Cervical dislocation was performed under light ether anesthesia on day 29 of the experiment.

Determination of tyrosine level in liver tissue. The tyrosine level was determined using the automatic analyzer of amino acids T-339 ("Microtechnology", Czech Republic); the studied samples were deproteinized by $6 \%$ sulphosalicylic acid. The tyrosine content was expressed in $\mathrm{mg} / \mathrm{g}$ of protein.

Determination of cortisol level in blood serum. Cortisol content was determined in serum using a direct quantitative immunoassay ("Cortisol ELISA"). The intensity of the color reaction is inversely proportional to the amount of cortisol in the sample, measured at a wavelength of $450 \mathrm{~nm}$.

Determination of tyrosine aminotransferase activity in the cytosolic fraction of hepatocytes. The tyrosine aminotransferase activity was determined by spectrophotometric assay using nhydroxybenzaldehyde, which is formed from the product of the deamination of tyrosine to 4hydroxyphenylpyruvate in an alkaline medium under the influence of air oxygen, which has a maximum absorption at $330 \mathrm{~nm}$. Incubation medium included: potassium-phosphate buffer $50 \mathrm{mM}$ (pH 7.4), $\alpha$ tyrosine $5 \mathrm{mM}, \alpha$-ketoglutarate $10 \mathrm{mM}$, and tissue extract. Reactive mixture was incubated at $37^{\circ} \mathrm{C}$, and $0.5 \mathrm{ml}$ samples were taken every 3-5 min and added to $2 \mathrm{ml}$ of $1 \mathrm{n} \mathrm{KOH}$ (Rain-Guion and Chambon, 1982). The enzyme activity was expressed in $\mathrm{nmol} / \mathrm{min} \times \mathrm{mg}$ of protein.

Determination of 4-hydroxyphenylpyruvate dioxygenase activity in the cytosolic fraction of hepatocytes. The 4-hydroxyphenylpyruvate dioxygenase activity was determined by spectrophotometric assay at $336 \mathrm{~nm}$ by the rate of formation of a complex between boric acid and enol tautomer. The reaction mixture consisted of solution containing $0.5 \mathrm{M}$ boric acid and $0.2 \mathrm{M}$ sodium phosphate, $\mathrm{pH} 6.2,0.005 \mathrm{M}$ pHPP dissolved in 0.05 $\mathrm{M}$ acetate, $\mathrm{pH} 6.0$, water, and enzyme added to a final volume of $3.3 \mathrm{ml}$ (Knox and Pitt ,1957).

Determination of aldehyde dehydrogenase activity in the cytosolic fraction of hepatocytes. ALDH3A1 activity was measured in $100 \mathrm{mM}$ $\mathrm{Na}_{2} \mathrm{HPO}_{4}$ buffer, pH 7.5, with $1.5 \mathrm{mM} \mathrm{NADP}{ }^{+}$and $1 \mathrm{mM}$ benzaldehyde at $340 \mathrm{~nm}$ wavelength (Parajuli et al., 2014). The enzyme activity was expressed in nmol $\mathrm{NADP}^{+} / \mathrm{min} \times \mathrm{mg}$ of protein.

The protein content was determined according to the Lowry method (Lowry et al., 1951).

Statistical analyses were performed using the Kruskal-Wallis analysis of variance and MannWhitney U test on SPSS statistical. All results were expressed as mean \pm standard deviation (SD) (mean \pm $\mathrm{SD})$. $\mathrm{P}<0.05$ was considered statistically significant. 
Results and discussion. Experimental results have shown that in conditions of acetaminopheninduced toxic liver injury a 5 -fold increase in tyrosine aminotransferase (TAT) activity in the cytosolic fraction of liver was observed in comparison with the control (Fig. 1). At the same time, in the liver tissue there was a 2-fold depletion of the tyrosine pool (Fig. 2).

It is known that tyrosine aminotransferase catalyzes the transamination reaction of tyrosine with the formation of 4-hydroxyphenylpyruvate (Lee and Facchini, 2011) - the first metabolite in the cascade of tyrosine transformation in hepatocytes, which can be further metabolized in homogentisate pathway to form fumarate and acetoacetate, or act as a metabolic precursor in the synthesis of ubiquinone.

The established fact of increased TAT activity against the background of a decrease in the free tyrosine level in conditions of toxic liver injury is likely to indicate an intensification of metabolic tyrosine transformations in the liver. Literary data indicate that to a large extent the observed activity changes are attributable to direct hormonal effects on the rates of TAT synthesis or degradation in the liver. TAT is the first enzyme in the catabolic pathway and is subjected to numerous hormonal control mechanisms; it has therefore been proposed as the rate limiting enzyme for hepatic tyrosine catabolism (Dickson et al., 1981). On the other hand, any possible direction of tyrosine metabolism under the conditions of toxic liver injury remains undiscovered.

It was interesting to note that in animals with toxic liver injury which were maintained in

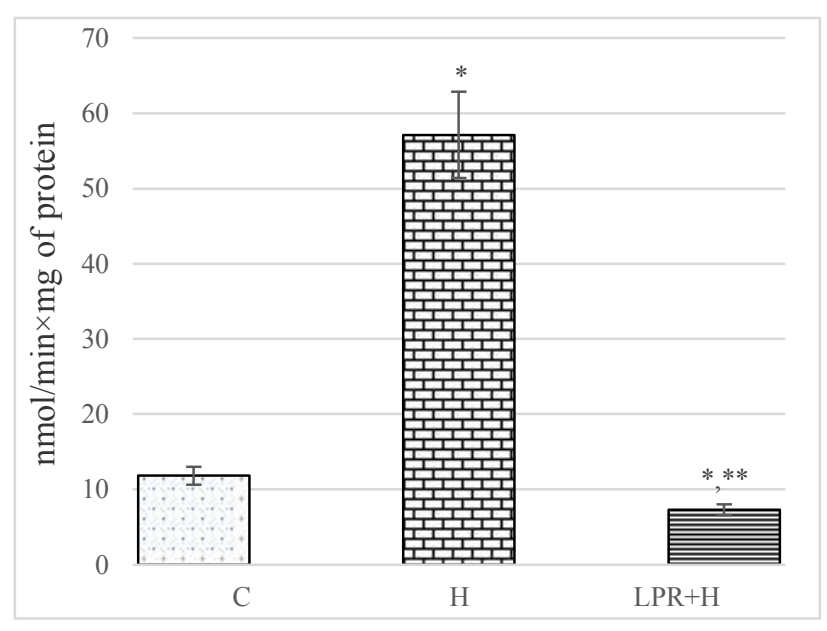

Fig. 1. The tyrosine aminotransferase activity in the rat liver cytosolic fraction under the conditions of alimentary protein deprivation and acetaminophen-induced hepatitis. conditions of alimentary protein deficiency, a 5-fold decrease in tyrosine level in the liver was observed (Fig. 2). The formation of endogenous tyrosine deficiency as a result of alimentary protein deficiency is likely to be accompanied by a tissue redistribution of this amino acid, which is further used for the formation of tissue proteins as well as for the synthesis of a number of biologically active substances. In particular, in the adrenal medulla tyrosine can be used for the synthesis of catecholamines, namely dopamine, noradrenaline and adrenaline; in melanocytes tyrosine may be a precursor of melanin pigment, and in the thyroid gland - as a precursor of iodine-containing hormones - triiodothyronine and thyroxin (Chernykh, 2013).

At the same time in animals of this group there was a decrease in TAT activity by 1.6 times (Fig. 1). According to (Mehere et al., 2010), an oxidation of thiol groups of TAT is the cause of enzyme inactivation. Taking into account that in the current experimental conditions there is an increased generation of ROS with the development of oxidative stress (Kopylchuk and Voloshchuk, 2016); the established fact of TAT inactivation is reasoned.

It is known that TAT activity is controlled by glucocorticoid hormones (Blind et al., 2012), namely cortisol (Panin and Usynin, 2008). At the same time, alterations in the catalytic activity always parallel changes in the enzyme amount changes, which is largely due to changes in the rate of aminotransferase synthesis (Granner and Hargrove, 1983).

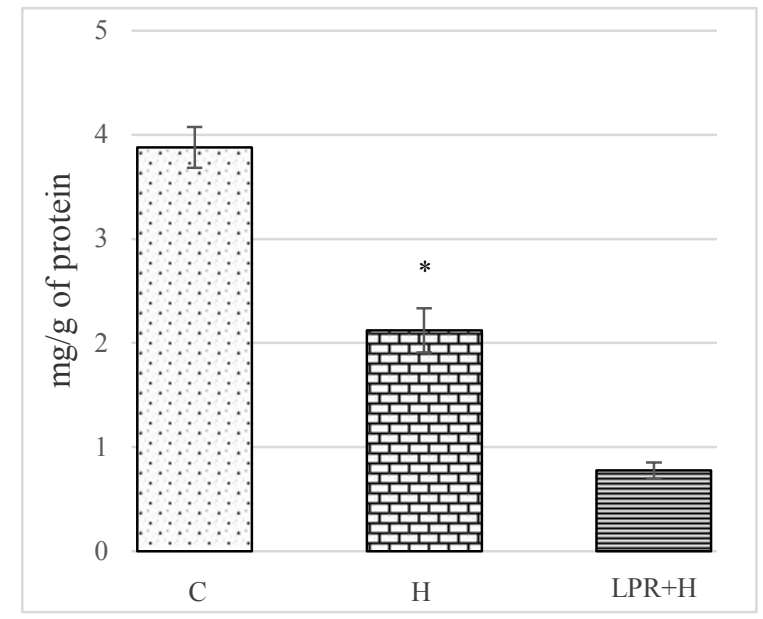

Fig. 2. The tyrosine level in the rat liver under the conditions of alimentary protein deprivation and acetaminophen-induced hepatitis.

Note (hereinafter): $C$ - animals receiving complete semi-synthetic ration; $H$ - animals with acetaminophen-induced hepatitis receiving complete ration; $L P R+H$ - animals with acetaminophen-induced hepatitis maintained on semisynthetic low-protein ration $(L P R+H)$.

* Significant difference with control group, $P \leq 0.05$

** Significant difference with control group and acetaminophen-induced hepatitis group, $P \leq 0.05$ 
Obtained experimental results have shown that in animals with acetaminophen-induced toxic liver injury the level of cortisol exceeds more than 2 times that of control. The results of studies are shown in Figure 3. Increased secretion of cortisol - the TAT inductor, is probably due to the formation of adaptive metabolic changes in response to administration of toxic acetaminophen doses. On the other hand, in rats with protein-deficiency and toxic liver injury the absence of significant changes in cortisol level compared to control (Fig. 3) indicates the disturbances in the adaptive capacity of the organism.

One of the possible ways to convert 4hydroxyphenylpyruvate - a product of the tyrosine aminotransferase reaction, is to use it as a molecular precursor in the synthesis of the benzoyl ring of ubiquinone (Szkopiñska, 2000; Kawamukai, 2016). An important metabolic role of ubiquinone is not only its participation in the oxidative phosphorylation as a component of the respiratory chain of mitochondria, but also as an acceptor of electrons from a number of dehydrogenases, in particular enzymes of fatty acids $\beta$-oxidation and synthesis of pyrimidine nucleotides, as well as an antioxidant (Nowicka and Kruk, 2010; Voloshchuk and Kopylchuk, 2015). Therefore, preservation of the ubiquinone pool is a prerequisite for the maintenance of the functional activity of hepatocytes.

Today it is known that in the mammals the precursor of the quinone ring is only 4hydroxybenzoate (4HB), which is derived from tyrosine through an uncharacterized set of reactions (Acosta et al., 2016; Awad et al., 2018). Among the enzymes of the metabolic pathway of 4hydroxyphenylpyruvate conversion to ubiquinone

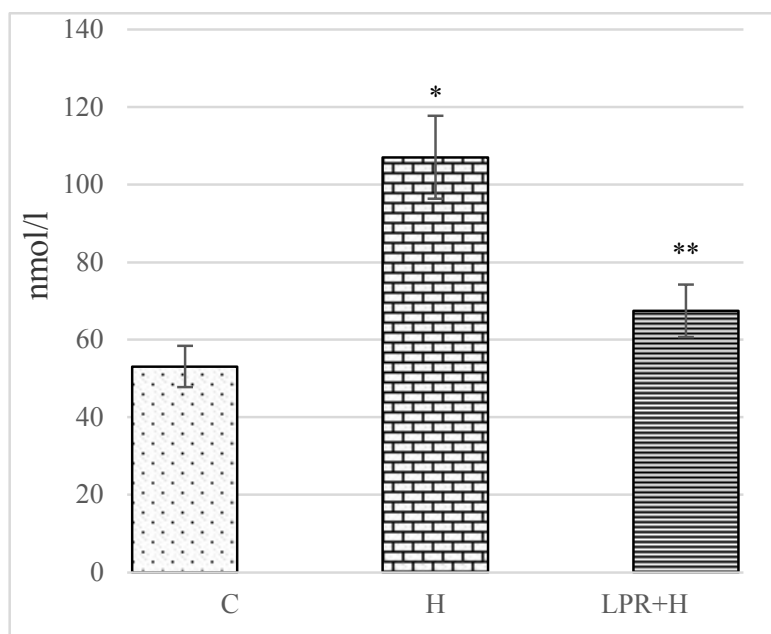

Fig. 3. The cortisol level in rat blood serum under the conditions of alimentary protein deprivation and acetaminophen-induced hepatitis there is aldehyde dehydrogenase ALDH3A1. The results of the studies have shown, that in conditions of toxic damage by acetaminophen there is a 2-fold decrease in the enzymatic activity of aldehyde dehydrogenase ALDH3A1 in cytosol of hepatocytes in comparison with control. The results of the research are shown in Figure 4.

At the same time, in protein-deficient animals with toxic liver damage there was a 4-fold decrease in enzymatic activity comparing to control parameters. The established fact indicates a possible disruption of the ubiquinone synthesis in animals with acetaminophen-induced toxic liver damage. Obtained data also confirm our earlier and published results (Voloshchuk and Kopylchuk, 2015), which showed both a reduction in the total ubiquinone content and changes in the ratio between its reduced and oxidized form in liver mitochondria under the given experimental conditions.

Another possible pathway for the formed in the tyrosine aminotransferase reaction 4hydroxyphenylpyruvate involves its transformation into homogentisate with the help of 4hydroxyphenylpyruvate dioxygenase. The final products of the homogentisate pathway of tyrosine metabolism in liver are fumarate and acetoacetate, which are used as substrates in energy metabolism reactions (Cotoia, 2014).

The experimental results have shown an increase in the activity of 4-hydroxyphenylpyruvate dioxygenase in animals with toxic liver injury, while the maximum increase in the enzyme activity was observed in animals with protein deficiency. In animals of this group the activity of 4hydroxyphenylpyruvate dioxygenase exceeded the control indices by 2.5 times. The results are shown in Figure 5.

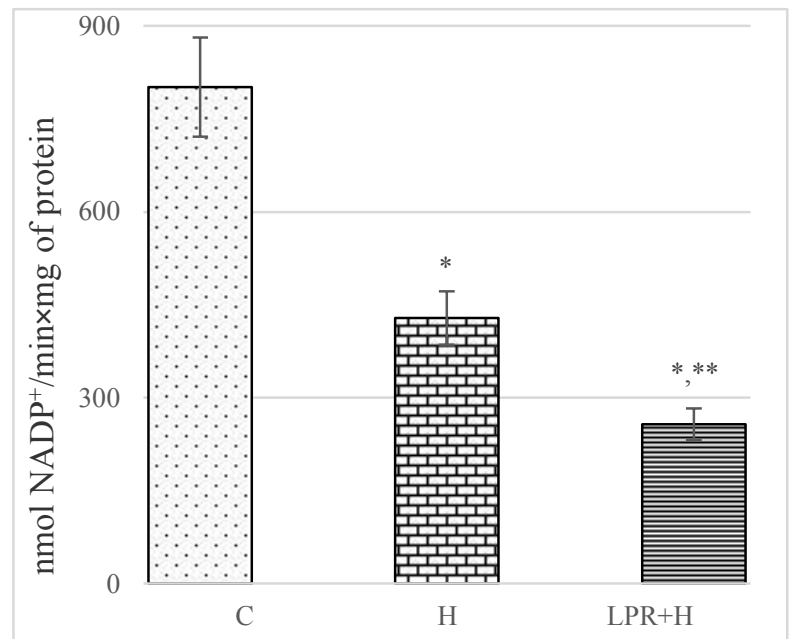

Fig. 4. The aldehyde dehydrogenase ALDH3A1 activity in the rat liver cytosolic fraction under the conditions of alimentary protein deprivation and acetaminopheninduced hepatitis 
We assume that under the current experimental conditions the increase in 4hydroxyphenylpyruvate dioxygenase activity is a compensatory reaction aimed at maintaining the energy status of the cell. Our previous studies have shown that in the conditions of acetaminopheninduced injury there was a formation of energy imbalance, which was more significant in animals with alimentary protein deficiency. In particular, a depletion of the adenine nucleotides pool, a decrease in the activity of the respiratory chain enzymes, as well as a disturbance of the ratio of $\mathrm{NAD}^{+} / \mathrm{NADH}$ was observed. Therefore, an activation of the homogentisate pathway of tyrosine metabolism in conditions of toxic liver injury against the background of alimentary protein deprivation reflects, in our opinion, the switching of metabolic pathways to the enhanced formation of energy metabolism substrates, since the disturbance of cellular energy supply is one of the mechanisms of cellular death.

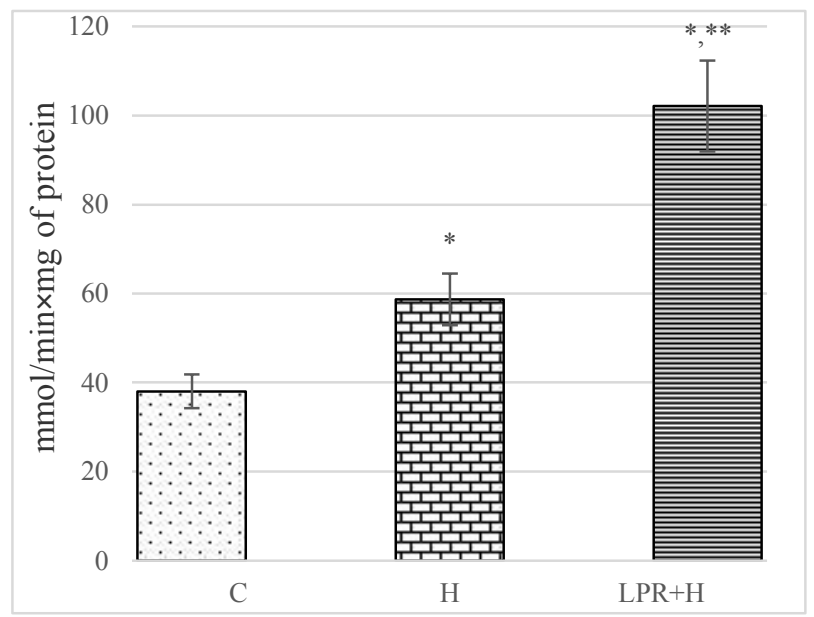

Fig. 5. The 4-hydroxyphenylpyruvate dioxygenase enzymatic activity in the rat liver cytosolic fraction under the conditions of alimentary protein deprivation and acetaminophen-induced hepatitis

The obtained results allow us to conclude that alimentary protein deficiency is an exacerbating factor that deepens the disturbances of the tyrosine metabolism in animals with the toxic liver injury. Furthermore, the pronounced exhaustion of the tyrosine pool is accompanied by the activation of the homogentisate pathway of its metabolism, as evidenced by the increase in the activity of 4hydroxyphenylpyruvate dioxygenase and simultaneous reduction in the aldehyde dehydrogenase ALDH3A1activity. The established changes open prospects to study the possible targets for the exogenous correction of metabolic disorders under the conditions of intoxication with acetaminophen, especially in people with protein deficiency.

Financial Disclosure: The work was done within framework of the "Biochemical and laserpolarimetric parameters of complex forecasting of metabolic disturbances" program, State Register No $0119 U 100717$.

\section{References:}

1. Acosta M, Vazquez Fonseca L, Desbats M, et al. Coenzyme $\mathrm{Q}$ biosynthesis in health and disease. Biochim Biophys Acta 2016;1857(8):1079-85.

2. Antonenko A, Blagaia A, Omelchuk S. et al. Mechanism of action of 4-hydroxyphenylpyruvate dioxygenase inhibitor herbicide on homoterm animals and humans. J Pre Clin Clin Res. 2015;9(2):145-150.

3. Awad A, Bradley M, Fernández-Del-Río L, Nag A, Tsui H, Clarke C. 2018. Coenzyme Q10 deficiencies: pathways in yeast and humans. Essays Biochem 2018;62(3):361-76.

4. Blind R, Pineda-Torra I, Xu Y, Xu H, Garabedian M. Ligand structural motifs can decouple glucocorticoid receptor transcriptional activation from target promoter occupancy. Biochem Biophys Res Commun 2012;420(4):839-44.

5. Chernykh A. Aromatic amino acids metabolism in humans exposed to experimental severe acute shortterm normobaric hypoxia. Human Ecology. 2013;7:5964.

6. Cotoia A, Scrima R, Gefter JV, Piccoli C, Cinnella G, et al. p-Hydroxyphenylpyruvate, an Intermediate of the Phe/Tyr Catabolism, Improves Mitochondrial Oxidative Metabolism under Stressing Conditions and Prolongs Survival in Rats Subjected to Profound Hemorrhagic Shock. PLOS ONE. 2014;9(3): e90917.

7. Dejong CH, van de Poll MC, Soeters PB, Jalan R, Olde Damink SW Aromatic amino acid metabolism during liver failure. $J$ Nutr. 2007;137:1579S-1585S.

8. Dickson A, Marston F, Pogson C. Tyrosine aminotransferase as the rate-limiting step for tyrosine catabolism in isolated rat liver cells. FEBS Letters 1981;127:28-32.

9. Granner D, Hargrove J. Regulation of the synthesis of tyrosine aminotransferase: the relationship to mRNATAT. Mol Cell Biochem 1983;53-54(1-2):11328.

10. Jin R, Banton S, Tran T, D., et al. Amino acid metabolism is altered in adolescents with nonalcoholic fatty liver disease - an untargeted, high resolution metabolomics study. J Pediatr 2016;172:14-19.

11. Kawamukai M. Biosynthesis of coenzyme Q in eukaryotes. Biosci Biotechnol Biochem 2016; 80(1):2333.

12. Knox WE, Pitt BM. Enzymic catalysis of the keto-enol tautomerization of phenylpyruvic acid. J Biol Chem. 1957;225(2):675-88.

13. Kopylchuk GP, Voloshchuk OM. Peculiarities of the free radical processes in rat liver mitochondria under toxic hepatitis on the background of alimentary protein deficiency. Ukr Biochem J 2016;88(2):66-72. doi: 10.15407/ubj88.02.066. 
14. Lee E, Facchini P. Tyrosine aminotransferase contributes to benzylisoquinoline alkaloid biosynthesis in opium poppy. Plant Physiol 2011;157(3):1067-78.

15. Lee W. Acetaminophen (APAP) hepatotoxicity - Isn't it time for APAP to go away? J Hepatol 2017;67:132431.

16. Lowry O, Rosebrough N, Farr A. Protein measurement with the Folin phenol reagent. $J$ Biol Chem. 1951;193(1):265-75.

17. Mehere P, Han Q, Lemkul J. Tyrosine aminotransferase: biochemical and structural properties and molecular dynamics simulations. Protein Cell 2010;1:1023-32.

18. Mobasher M, Valverde A. Protein tyrosine phosphatase deficiency protects against the induction of the early apoptosis by paracetamol in hepatocytes. An $R$ Acad Nac Farmac 2014;80(4):666-82.

19. Mukherjee S, Vaidyanathan K, Vasudevan D, Das,S. Role of plasma amino acid and gaba in alcoholic and non-alcoholic liver disease - a pilot study. Indian J Clin Biochem 2010;25(1):37-42.

20. Nowicka B, Kruk J. Occurrence, biosynthesis and function of isoprenoid quinones. Biochim Biophys Acta 2010;1797(9):1587-605.

21. Pahari SK, Ghosh S, Halder S, Jana M (2016) Role of Coenzyme Q10 in human life. RJ PT 9(6):635-640.

22. Panin LE, Usynin IF. Role of glucocorticoids and resident liver macrophages in induction of tyrosine aminotransferase. Biochemistry (Moscow) 2008;73:305-309
23. Parajuli B, Fishel M, Hurley T. Selective ALDH3A1 inhibition by benzimidazole analogues increase mafosfamide sensitivity in cancer cells. $J$ Med Chem 2014;57(2):449-61.

24. Rain-Guion M, Chambon H. Tyrosine amino transferase as a teaching enzyme in biochemistry class experiment. Biochem Educ 1982;10(3):88-92.

25. Ramachandran A, Jaeschk H. Mechanisms of acetaminophen hepatotoxicity and their translation to the human pathophysiology. JCTR 2017;3(1):157-69.

26. Rass IT. Blood content of tyrosine is an index of glucocorticoid action on metabolism. Biochemistry (Mosc). 2010;75(3):353-66.

27. Reeves P, Nielsen F, Fahey G. AIN-93 purified diets for laboratory rodents: final report of the American Institute of Nutrition Ad Hoc Writing Committee on the Reformulation of the AIN-76A Rodent. $J$ Nutr. 1993;123(11):1939-51.

28. Szkopiñska A. Ubiquinone. Biosynthesis of quinone ring and its isoprenoid side chain. Intracellular localization. Acta Biochim Pol 2000;47(2):469-80.

29. Voloshchuk ON, Kopylchuk GP. The ratio of ubiqiunon redox forms in the liver mitochondria under toxic hepatitis induced on the background of alimentary protein deficiency. Vopr Pitan. 2015;84(5):82-7.

30. Yoon E, Babar A,Choudhary M, Kutner M, Pyrsopoulos N. Acetaminophen-induced hepatotoxicity: a comprehensive update. JCTH 2016;4(2):131-42.

\title{
АКТИВНІСТЬ ЕНЗИМІВ МЕТАБОЛІЗМУ ТИРОЗИНУ У ПЕЧІНЦ ЩУРІВ ЗА УМОВ АЦЕТАМІНОФЕН-ІНДУКОВАНОГО ГЕПАТИТУ НА ТЛІ ДЕФІЦИТУ ПРОТЕЇНУ
}

\author{
О. М. Волощук, Г. П. Копильчук
}

Вклад дисметаболічних перетворень окремих амінокислот у формування індукованого препаратами ушкодження клітин печінки залишається не до кіния вивченим. Метою иьього дослідження було дослідження вмісту тирозину в печінці та активності ензимів його метаболізму: тирозинамінотрансферази, 4гідроксифенілпіруват діоксигенази, альдегіддегідрогенази ALDH3A1 за умов токсичного ушкодження, індукованого ацетамінофеном на тлі аліментарного дефіцитту протеїну. Визначення вмісту тирозину в депротеїнізованих 6\% сульфосалічиловою кислотою екстрактах тканини печінки проводили за допомогою автоматичного аналізатора амінокислот T-339 («Mikrotechna», Чехія). Активність ензимів визначали спектрофотометрично: тирозинамінотрансферазну активність - за кількістю утвореного 4гідроксибензальдегіду, щзо має максимум поглинання при $\lambda 330$ нм, 4-гідроксифенілпіруватдіоксигеназну активність - при $\lambda 336$ нм, альдегіддегідрогеназну - при $\lambda 340$ нм. Результати проведених досліджень показали, щуо у тварин з токсичним ушкодженням печінки, які утримувалися за умов аліментарного дефіциту білка, спостерігається 5-кратне зниження вмісту тирозину в печіниі. У той же час у тварин иієї групи спостерігалося зниження активності тирозинамінотрансферази в 1,6 рази, зменшення активності альдегіддегідрогенази ALDH3A1 в 4 рази на тлі підвищення активності 4-гідроксифенілпіруватдіоксигенази в 2,5 рази порівняно з контрольними параметрами. Зроблено висновок, шьо аліментарний дефіцит протеїну $\epsilon$ фактором, що призводить до поглиблення порушень метаболізму тирозину у тварин з токсичним ушкодженням печінки. Виражене виснаження пулу тирозину за досліджуваних експериментальних умов супроводжується активачією гомогентизинового иляху його метаболізму, про щчо свідчить підвищення 4гідроксифенілпіруватдіоксигеназної активності та одночасне зниження активності альдегіддегідрогенази ALDH3A1. Встановлені зміни відкривають перспективи для вивчення можливих міменей екзогенної корекиї порушень обміну речовин за умов інтоксикації ацетамінофеном, особливо у людей з аліментарним дефіцитом протеїну.

Ключові слова: тваринна модель, печінка, ацетамінофен, аліментарний дефіцฺт протеїну, тирозин 